\title{
Nominalization in TIV
}

\section{Stephen Shiaondo Ajim a, lorember Margaret N. ${ }^{b,}{ }^{*}$}

a National Institute for Nigerian Languages, Aba, Abia State.

${ }^{\mathrm{b}}$ Department of English, Yobe State University, Damaturu.

*Corresponding author Email: ambreenkharbe72@gmail.com; megiorember@gmail.com

DOI: https://doi.org/10.34256/ijll2112

Received: 22-03-2021, Accepted: 28-03-2021; Published: 30-03-2021

Abstract: Nominalization is a linguistic process of deriving nouns from other word classes or linguistic units. Nominalization is evident in many languages of the world. The Tiv language also exhibits nominalization. This paper critically analyses nominalization in Tiv. The objectives of the paper are: to determine the processes through which nominalization takes place in the Tiv language, the extent to which the processes of nominalization are productive in the Tiv language, and the classes of words and linguistic units that are nominalized in Tiv. Data were sourced from the native speakers of Tiv using the researcher - participant technique. The researchers documented the lexical items used during the interaction, determine the basic components of the lexical items and the word classes such lexical items belonged to. The intuitive knowledge of the researchers as the native speakers of the language was harnessed. The secondary data were sourced from the already existing literatures such as textbooks, journals and the internet. The theory adopted in the paper is Hokett's (1954) structural theory whose models are the Item-and-Process (I.P) and Item-and-Arrangement (I.P). It has been found out that the processes through which nominalization takes in the Tiv language are prefixation, prefixation plus some modifications, tonality and desententialization (sentence deconstruction). These processes are discovered to be very productive in nominalization in Tiv. It has also been found out that verbs roots and adjectives are the classes of words that are nominalized (lexical nominalization) in the Tiv language together with sentences (syntactic nominalization).

Keywords: Nominalization, Nominalizer, Prefixation, Modification, Tonality and Desententialization.

\section{Introduction}

Linguistics as a field of study has many branches which morphology is one of the branches. Morphology is very essential as it studies the internal structure of words and words formation processes. Nominalization as a morphological process is a process of deriving a noun from some other word classes. Nominalization has been attested in many world languages such as English, Igbo, Tee among others. Nominalization is also evident in Tiv, one of the Bantu groups of languages majorly spoken in Benue State. This paper seeks to analyse nominalization as a morphological process in the Tiv language.

\section{Methodology}

The methodology adopted in this paper is descriptive in nature. The paper uses the primary and secondary sources of data. The primary data were sourced from the native speakers of Tiv as they interact with the researchers. In such interactive situation, the researchers wrote down some lexical items used, identified the basic components such lexical items have, determine the world classes such lexical items belong to. The intuitive knowledge of the researchers as the native speakers immensely helped in data gathering, refinement and subsequent analysis. The secondary sources of data were from the already existing literatures such as textbooks, journals, internet among others. Nominalized nouns were picked from some of the literatures in Tiv and analysed. 
Morphology and Morphological Processes

Haspelmath and Sims (2010) define morphology as "the study of the internal structure of words." This means morphology concerns with the shapes of words and their components. Corroborating, Badejo (2004:7) defines morphology as "the branch of linguistics that is the repository of the information on the structure of words." From the above definitions, it is crystal clear that morphology studies the structure of words and the processes of word-formation. According to Badejo (2004), there are three major processes of word-formation viz: affixation, reduplication and modification. Affixation is the process whereby an element is attached into an existing root or stem which could either be a prefix or suffix (Matthew, 1974). Reduplication is a process whereby another shade of meaning is produced by repeating the whole or part of the root (Matthew, 1974). Examples, hush-hush, goody-goody, hanky-panky. Modification to Matthew (1974) is a process by which a whole part of the shape of a root is structured or qualified to get another meaning as in man - men, foot - feet. Yule (1966) identifies compounding as a word-formation process. Compounding to him is a process of joining two separate words to produce a single form as in bookcase, finger-print among others.

In nominalization as a derivative process, the aforementioned processes (affixation, modification, reduplication, compounding among others) are operational in languages. This however does not mean all of the processes must be productive in nominalization in all the languages.

\section{Nominalization as a derivative process}

According to Anyanwu and Omego (2015), nominalization is a process of deriving a noun from some other word classes (as in 'ability derived from 'able', 'failure' derived from 'fail', 'dancing' derived from 'dance') or the derivation of a noun phrase from an underlying clause (as in "His answering the phone was surprising" derived from "He answered the phone). From the foregone examples, 'ability' as a noun is derived from the adjective able', 'failure' as a noun derived from the verb 'fail', 'dancing' a gerundive noun derived from the verb 'dance'.

Chomsky (1970) posits has two main types of nominalization: lexical and syntactic (grammatical) nominalization. Lexical nominalization produces linguistic forms belonging to the lexical category of noun while syntactic nominalization creates nominal expressions that do not have lexical status (Shibatani and Awadh, 2009). Alternatively lexical nominalization is a derivational process of word-formation where nouns are derived from some other lexical categories, typically a verb or an adjective, by modifying the root (Anyanwu and Omego, 2015). Example, 'legal, legalize, and legalization (Anyanwu and Omega, 2015).

\section{Previous studies on Nominalization}

Scholars have worked on nominalization in various languages. Dauda (1971) researched on "lexicalist hypothesis and Hausa". In this study, Dauda examined nominalization in Hausa in the context of Chomsky's lexicalist hypothesis. He identifies derived norminalis and gerundive norminals in Hausa. He also explicates with examples. The study relates to the present study because it centres on nominalization and a Nigerian language (Hausa). The present study however focuses on the Tiv language. Similarly, Anyanwu and Omego (2015) researched on "aspects of deverbal nominalization in Tee", an Ogoni (Kegboid) (Ikoro, 1990) group of languages spoken in the Tee district of Tai Local Government in Rivers State, Nigeria (Anyanwu and Omego, 2015). The study finds Agentive norminalization (verb root: t̄̄gś 'teach'-derived agentive: $n \bar{\varepsilon} \bar{\varepsilon}$-tōg's 'teacher'), Gerundive nominalization (verb root: dé 'eat' - derived gerunds: lò-dé-dé (act of) eating'), Action noun (Non-Gerundive) nominalization (verb root: dém 'create' - derived action nominal: dém 'creation)', infinitive nominalization (verb root: t̄̄gét'teach' - derived infinitive: gìgà- t̄̄gé 'to teach'), state (qualificative) noun nominalization (verb root: lúkpè 'be sweet' - Derived infinitive: kpé 'sweetness) as type of deverbal nominalizations evident in Tee language. The study relates to the present too. Its point of departure from the present study is that, it looks at Tee as a language and restricted to lexical nominalization. The present study seeks to analyse both lexical and grammatical (syntactic) nominalization in the Tiv language. Nominalization is also evident in Igbo language. Maduagwu (2010) researched on 'aspects of nominal derivation in Igbo'. She examines this linguistic phenomenon and finds two categories of derived nouns in Igbo language viz: nouns formed from nominal compounding and nouns formed from sentences. The examples of the nouns formed from nominal compounding are as follows: 
N1

a.

a. onye 'person'

b. 'ndi 'people'

c. ụgbo vehicle'

d. anya 'eye'

e. aka 'hand'
N2

$+\quad$ agha

$+\quad$ ahịa

'market'

$+\quad$ elu

'top'

ọku

'fire'

ike

'strength'
N3

$\rightarrow \quad$ Nominal compound

onyeagha 'soldier'

$\rightarrow \quad$ ndịahịa 'merchant'

$\rightarrow \quad$ ụgbọelu 'aeroplane'

$\rightarrow \quad$ anyaọkụ 'jealousy'

$\rightarrow \quad$ akaike 'stinginess'

Source: Maduagwu (2010: $1-3$ )

The examples of nouns formed from sentences as given by Maduagwu (2010:4) are as follows:

\section{Derived Nouns}
a. Nwakàego
(female person's name)
b. Ndùbùàkù
'female person's name'

\section{Sentences}

From Nwa kà ego

child surpasses money

From Ndù bù àkù

'life is wealth'

The study also examines how nouns denoting ideas of excessiveness could be derived, nouns derived through pronominal ${ }^{2}$ position-switching and auxiliary deletion among others are examined. From all the above researches examined, none considers the Tiv language majorly spoken in Benue State hence the need for the present study.

\section{Theoretical Framework}

This paper is anchored on Hockett's (1954) structural theory whose models are Item-and-Arrangement (I.A) and Item and Process (I.P). The Item-and-Arrangement (I.A) model considers both roots and affixes as morphemes with at least one allomorph of each, stored in the lexicon (Maxwell, 1998). This means that in 'independently' the root is 'depend' and the other morphemes 'in-', '-ent', and 'ly' are affixes and are both listed in the lexicon. Alternatively, the Item-and-Arrangement theory looks at the analysis of the structure of words by decomposing or separating words into their immediate components (Ajim, 2018). The model sees inflectional formatives and derivation as a process of arrangement of items such as affixation of bound morphemes onto the base in its simplest form, this manner of analyzing word form (i.e. Item-and-Arrangement) treats words as if they were made of morphemes put after each other (concatenated) like beads on a string (Ajim, 2018).

Item-and-Process model has it that a word form is the result of applying rules that alter a word-form or stem in order to produce a new one. For example, an inflectional rule takes a stem, changes it as is required by the rule, and an outputs a word form; a derivational rule takes a stem, changes it as per its own requirements, and outputs a derived word; a compounding rule takes a word form and similarly outputs a compound stem (Spencer, 1991). In other words Item-and-Process treats word-formation as not only arrangement of linguistic elements but also the involvement of processes. The model holds that affixes are processes, that is, affixes are morphological rules that exist in a separate component of grammar. Based on the model, in the word singer, it is only the root 'sing' that is listed in the lexicon, the suffix '-er' is only a morphological rule of deriving a noun from the verb 'sing'. The two theoretical models examined here are suitable in the analysis of nominalization in Tiv. The application of the models helped in accounting for the different linguistic components that come together to derive nouns from 
other words classes and the processes involved whether affixation, modification, compounding, reduplication, tonality, sentence deconstruction (desententializaton) among others

\section{Nominalization in Tiv}

In the Tiv language, nominalization takes the following processes (Table 1-4):

(a) Prefixation: This is a type of affixation where a linguistic element is attached to the beginning of a root word. The element that is attached to the initial position of the root word is a prefix. Prefixation is a very productive process in nominalization in the Tiv language as seen below:

Table 1 Table of derivation of nouns (nominalization) from verbs through prefixation

\begin{tabular}{|l|l|l|l|}
\hline S/No & Prefix & Verb root & Noun Derived \\
\hline 1 & m- & ande (resurrect/appear) & m-ande (resurrection/appearance) \\
\hline 2 & m- & civir (worship) & m-civir (worship) \\
\hline 3 & m- & de (forgive ) & m-de (forgiveness) \\
\hline 4 & m- & ember (rejoice) & m-ember (joyfulness) \\
\hline 5 & m- & gbide (beat) & m-gbide (act of beating) \\
\hline 6 & m- & hia (matured) & m-hia (maturity/maturation) \\
\hline 7 & m- & kôôm (correct/interdict) & m-kôôm (correction/interdiction) \\
\hline 9 & m- & soo (love) & m-soo (act of loving) \\
\hline 10 & m- & tsua (select/remove ) & m-tsua/mtsugh/selection/removal \\
\hline 11 & m- & umbur (remember) & m-time (digging) \\
\hline 12 & m- & venda (refuse/reject) & m-vende/mvenda (refusal/rejection) \\
\hline 13 & m- & yange (prevent) & m-yange (prevention) \\
\hline 14 & m- & ye (eats) & m-ye (food/the act of eating) \\
\hline 15 & m- & tôv (investigate ) & mtôv (investigation) \\
\hline
\end{tabular}

As buttressed from the above table, it is crystal clear that nouns can be derived from words by prefixing ' $\mathrm{m}$ ' to the root verbs proving prefixation as a productive process in nominalization in Tiv. From the table 2 , it could be observed that ' $m$-' used in the above example has no meaning on its own but when added to the root verbs, the verbs are changed to nouns making the prefix ' $m-$ ' as used in the above examples as a nominalizer.

Table 2 Table of derivation of nouns (nominalization) from verbs through prefixation with some modifications

\begin{tabular}{|l|l|l|l|}
\hline S/No & Prefix & Verb root & Noun Derived \\
\hline 1 & m- & $\begin{array}{l}\text { gema } \\
\text { "change/turn" }\end{array}$ & $\begin{array}{l}\text { mgem } \\
\text { "ynamism" }\end{array}$ \\
\hline 2 & m- & $\begin{array}{l}\text { kaa(n) } \\
\text { "say(ing)" }\end{array}$ & $\begin{array}{l}\text { mkaanem } \\
\text { "speech/saying" }\end{array}$ \\
\hline 3 & m- & $\begin{array}{l}\text { zua } \\
\text { 'join' }\end{array}$ \\
\hline 4 & er(en) & "union/congregation" \\
\hline
\end{tabular}




\begin{tabular}{|l|l|l|l|}
\hline & & "do(ing)" & "acts/actions \\
\hline 5 & $\mathrm{i}$ & $\begin{array}{l}\text { lam } \\
\text { "speak" }\end{array}$ & $\begin{array}{l}\text { ilyam } \\
\text { "speech" }\end{array}$ \\
\hline 6 & $\mathrm{i}$ & $\begin{array}{l}\text { ituhanev } \\
\text { "insult" }\end{array}$ \\
\hline 7 & $\mathrm{i}$ & $\begin{array}{l}\text { "insult" } \\
\text { sar(en) }\end{array}$ & $\begin{array}{l}\text { isharen } \\
\text { "desire(ing)" }\end{array}$ \\
\hline 8 & $\mathrm{i}$ & $\begin{array}{l}\text { maa } \\
\text { "build" }\end{array}$ & $\begin{array}{l}\text { imaagh } \\
\text { "bulding" }\end{array}$ \\
\hline
\end{tabular}

From the above presentation, it could be observed that some verbs roots are changed to nouns through prefixation and some modifications. In the above table, ' $m$ ', ' $a$ ' and ' $i$ ' are used as prefixes. In the first example ' $m$-' is prefixed to the root 'gema' (change/turn) and the last letter of the root verb 'a' deleted to derive the noun ' $m$ $\mathrm{gem}^{\prime}$ (dynamism). In the second example, ' $\mathrm{m}$ ' is prefixed to 'kaa' (say) and (-n) suffixed to 'kaa' to produce 'kaan' (saying) and 'em' further suffixed to derived 'mkaanem' (speech saying) which is a noun. In example three, ' $m$ ' is prefixed to 'zua' (join) and /ua/ replaced with /oo/ to derive 'mzoo (union/congregation). In example four, the base verb 'er'(do) has been prefixed with ' $a$ ' and inflected with its continuous tense '-en' to derive 'aeren' (acts/actions) which is a noun. In the same manner, ' $i$ ' is attached to 'lam' (speek), 'tuha' (insult), 'sar'(desire) an 'maa' build at the beginning with addition of certain letters at the medial and final positions to derive the nouns: "ilyam (speech), ituhanev(insult) and isharen (desire)."

Table 3 Table of nominalization through prefixation of ' $m$ ', 'mba', ' $i$ ' or ' $u$ ' to adjectives

\begin{tabular}{|l|l|l|l|}
\hline S/No & Prefix & Base adjective & Noun derived \\
\hline 1 & m- & ange (sour) & m-ange (sourness) \\
\hline 2 & m- & doo (good) & m-doo (goodness) \\
\hline 3 & m- & hange (necessary) & m-hange (necessity) \\
\hline 4 & m- & kundu (cold) & m-kundu (coldness) \\
\hline 5 & m- & lihe (long) & m-lihe (length) \\
\hline 6 & m- & tav (tall) & m-tav (tallness/height) \\
\hline 7 & m- & saanyol (happy) & m-msaanyol (happiness) \\
\hline 8 & i- & lihe (long) & i-lihen (length) \\
\hline 9 & u- & hwev (lazy) & u-hwev (laziness) \\
\hline 10 & mba- & atseregh (tricks) & mba-aatseregh (tricksters) \\
\hline
\end{tabular}

The above table 3 shows the derivational formation of nouns from adjectives. It could be observed that nouns are derived from adjectives by prefixing ' $m$ ', ' $m b a^{\prime}$, ' $i$ ' and ' $u$ ' to the base of the adjectives. These prefixes are bound morphemes and have no meaning when they stand alone but in the context they are used, they function as nominalizers.

Table 4 Table of nominalization of nouns from adjectives through prefixation with some modifications

\begin{tabular}{|l|l|l|l|}
\hline S/No & Prefix & Base adjective & Noun derived \\
\hline 1 & m- & doo(m) (good/beautiful) & m-doom (beauty) \\
\hline 2 & m- & yuha (heavy) & m-yohom (heaviness) \\
\hline
\end{tabular}




\begin{tabular}{|l|l|l|l|}
\hline 3 & m- & vihi(m) (ugly) & m-vihim (ugliness) \\
\hline 4 & i- & bume (stupid/foolish) & i-byumegh (stupidity/foolishness) \\
\hline 5 & i- & yuusu (foolish) & iyuusugh (foolishness) \\
\hline
\end{tabular}

From the table 4 demonstration, it could be observed that some adjectives can be nominalized by prefixing and suffixing linguistic elements to the base as in " $m+$ doo (good/beautiful) $+m \rightarrow$ mdoom (beauty)," some can be nominalized by prefixing, infixing and suffixing linguistic elements to the base as in " $i+$ bume (stupid/foolish) $+-y-+g h \rightarrow$ ibyumegh (stupidity/foolishness)" where 'i-' is the prefix, 'bume' is the root or base, '- $y-$ ' is an infix and '-gh' is a suffix.

Table 5 Table of nominalization through tonality

\begin{tabular}{|c|c|c|}
\hline S/No & Word/word class & Noun derived through tonal variation \\
\hline 1 & $\begin{array}{l}\text { àmbē (verb) } \\
\text { "to suck" }\end{array}$ & $\begin{array}{l}\text { ámbé } \\
\text { "crocodile" }\end{array}$ \\
\hline 2 & $\begin{array}{l}\text { bēhdè (verb) } \\
\text { "touched" }\end{array}$ & $\begin{array}{l}\text { béndé } \\
\text { "kind of amulet" }\end{array}$ \\
\hline 3 & $\begin{array}{l}\text { dūrà (verb) } \\
\text { "thunder" }\end{array}$ & $\begin{array}{l}\text { dúrá } \\
\text { coccidiosis" }\end{array}$ \\
\hline 4 & $\begin{array}{l}\text { dāā (verb) } \\
\text { "to push" }\end{array}$ & $\begin{array}{l}\text { dàà, dáà } \\
\text { "table", "a traditional game }\end{array}$ \\
\hline 5 & $\begin{array}{l}\text { gbòr (adjective), gbór (verb) } \\
\text { "age grade", "to pluck unripe fruits } \\
\text { roughly" }\end{array}$ & $\begin{array}{l}\text { gbōr } \\
\text { "stomach" }\end{array}$ \\
\hline 6 & $\begin{array}{l}\text { gbēr (verb) } \\
\text { "to cut down" }\end{array}$ & $\begin{array}{l}\text { gbér } \\
\text { "gallon" }\end{array}$ \\
\hline 7 & $\begin{array}{l}\text { jijà (adjective) } \\
\text { "a spoilt object" }\end{array}$ & $\begin{array}{l}\text { Jijá } \\
\text { "castor plant" }\end{array}$ \\
\hline 8 & $\begin{array}{l}\text { jìr (verb) } \\
\text { 'to cook' }\end{array}$ & $\begin{array}{l}\text { jē } \bar{\imath} \mathrm{r} \\
\text { "a place" }\end{array}$ \\
\hline 9 & $\begin{array}{l}\text { kōr } \\
\text { "to sew" }\end{array}$ & $\begin{array}{l}\text { kór, kòr } \\
\text { "rope", "sasswood" }\end{array}$ \\
\hline 10 & $\begin{array}{l}\text { ìpyúsù (adjective) } \\
\text { "uncircumcised" }\end{array}$ & $\begin{array}{l}\text { ípyūsū } \\
\text { "loamy soil" }\end{array}$ \\
\hline 11 & $\begin{array}{l}\text { Iū (verb) } \\
\text { "was" }\end{array}$ & $\begin{array}{l}\text { lú } \\
\text { "mortar" }\end{array}$ \\
\hline 12 & $\begin{array}{l}\text { nyiàn (adjective) } \\
\text { "red" }\end{array}$ & $\begin{array}{l}\text { nyīán } \\
\text { "today" }\end{array}$ \\
\hline 13 & $\begin{array}{l}\text { nyiàr (verb) } \\
\text { "to wink as somebody" }\end{array}$ & $\begin{array}{l}\text { nyíār } \\
\text { "lightening" }\end{array}$ \\
\hline
\end{tabular}




\begin{tabular}{|c|c|c|}
\hline 14 & $\begin{array}{l}\text { pēv (verb) } \\
\text { "to touch and feel" }\end{array}$ & $\begin{array}{l}\text { pèv, pév } \\
\text { "to make a whole in something", "a slope" }\end{array}$ \\
\hline 15 & $\begin{array}{l}\text { pēr (verb) } \\
\text { to touch and feel" }\end{array}$ & $\begin{array}{l}\text { pér } \\
\text { "war shield or floor cover for farming" }\end{array}$ \\
\hline 16 & $\begin{array}{l}\text { sùlè (verb) } \\
\text { "to become cold, to die" }\end{array}$ & $\begin{array}{l}\text { súlé, súlè } \\
\text { 'farm' "money" }\end{array}$ \\
\hline 17 & $\begin{array}{l}\text { tsā (verb) } \\
\text { "sleep over" }\end{array}$ & $\begin{array}{l}\text { Tsá } \\
\text { "farmland" }\end{array}$ \\
\hline 18 & $\begin{array}{l}\text { tàr (verb) } \\
\text { 'spread' }\end{array}$ & $\begin{array}{l}\text { tár } \\
\text { 'nation' }\end{array}$ \\
\hline 19 & $\begin{array}{l}\text { ùmā (verb) } \\
\text { 'dried' }\end{array}$ & $\begin{array}{l}\text { úmā } \\
\text { "life" }\end{array}$ \\
\hline 20 & $\begin{array}{l}\text { úsé (verb) } \\
\text { "partially dried" }\end{array}$ & $\begin{array}{l}\text { ūsè } \\
\text { "down" }\end{array}$ \\
\hline 21 & $\begin{array}{l}\text { wúà (verb), wùá (verb) } \\
\text { "to kill" "to grind" }\end{array}$ & $\begin{array}{l}\text { wúā } \\
\text { "guinea-corn" }\end{array}$ \\
\hline 22 & $\begin{array}{l}\text { wùhē (verb) } \\
\text { "to uproot, to close" }\end{array}$ & $\begin{array}{ll}\text { wúhé, } & \text { wúhē } \\
\text { "coldness" } & \text { "co-wife" }\end{array}$ \\
\hline 23 & $\begin{array}{l}\text { yàngè (verb) yàngē (verb) } \\
\text { "to dress with charms," "to prevent, to } \\
\text { prohibit" }\end{array}$ & $\begin{array}{l}\text { yángé } \\
\text { "sun/day" }\end{array}$ \\
\hline 24 & $\begin{array}{l}\text { tsēr (adjective), tsèr (verb) } \\
\text { "hot or warm", "to be neat/multiply" }\end{array}$ & $\begin{array}{l}\text { tsér } \\
\text { "a local Tiv plate" }\end{array}$ \\
\hline 25 & $\begin{array}{l}\text { zèndè (verb) } \\
\text { "to walk" }\end{array}$ & $\begin{array}{l}\text { zéndē } \\
\text { "a journey" }\end{array}$ \\
\hline
\end{tabular}

From the table 5 demonstration, it could be observed that some Tiv verbs and adjectives can be nominalized by variation in tone. In the above examples, changes in tonal marks change adjectives and verbs to nouns as in jijà [d3ìd3à] - a spoilt object $\rightarrow$ jijá [d3ìd3á] - castor plant, and bēndè [bēndè] - touched $\rightarrow$ béndé [béndé] - a kind of 'amulet'. In line with the Item-and-Arrangement (I.A) and Item-and-Process (I.P) models, the linguistic items used in the above examples are the words and the tonal marks, and the process employed to nominalized the adjectives and verbs is tonality and the tonal marks used are the nominalizers.

Table 6 Table of nominalization through the process of desententialization (sentence deconstruction)

\begin{tabular}{|l|l|l|}
\hline S/No & \multicolumn{1}{|c|}{ Sentences } & \multicolumn{1}{c|}{$\begin{array}{c}\text { Nouns derived through } \\
\text { desententialization }\end{array}$} \\
\hline 1 & $\begin{array}{l}\text { mba ngohol kpandegh } \\
\text { they collecting tax } \\
\text { "they are collecting tax" }\end{array}$ & $\begin{array}{l}\text { mbangoholkpandegh } \\
\text { "tax collectors" }\end{array}$ \\
\hline
\end{tabular}




\begin{tabular}{|c|c|c|}
\hline 2 & $\begin{array}{l}\text { mba tan kpandegh } \\
\text { they throwing/paying tax } \\
\text { "they are paying tax" }\end{array}$ & $\begin{array}{l}\text { mbatankpandegh } \\
\text { "tax payers" }\end{array}$ \\
\hline 3 & $\begin{array}{l}\text { mba maan kwagh } \\
\text { they building something } \\
\text { "they are building something" }\end{array}$ & $\begin{array}{l}\text { mbamaankwagh } \\
\text { "builders/masons" }\end{array}$ \\
\hline 4 & $\begin{array}{l}\text { mba nan jighjigh } \\
\text { they giving believe } \\
\text { "they are believing" }\end{array}$ & $\begin{array}{l}\text { mbananjighjigh } \\
\text { "believers" }\end{array}$ \\
\hline 5 & $\begin{array}{l}\text { mba man kwagh } \\
\text { they drinking something } \\
\text { "they are drinking something" }\end{array}$ & $\begin{array}{l}\text { mbamankwagh } \\
\text { "drinkers" }\end{array}$ \\
\hline 6 & $\begin{array}{l}\text { mba eren tom } \\
\text { they doing work } \\
\text { "they are working" }\end{array}$ & $\begin{array}{l}\text { mbaerentom } \\
\text { "workers/labourers" }\end{array}$ \\
\hline 7 & $\begin{array}{l}\text { mba vinen amar } \\
\text { they dancing dance } \\
\text { "they are dancing" }\end{array}$ & $\begin{array}{l}\text { mbavinenamar } \\
\text { "dancers" }\end{array}$ \\
\hline 8 & $\begin{array}{l}\text { mba wan atsam } \\
\text { they inserting/singing songs } \\
\text { "they are singing" }\end{array}$ & $\begin{array}{l}\text { mbwanatsam } \\
\text { "singers" }\end{array}$ \\
\hline 9 & $\begin{array}{l}\text { mba fan kwagh } \\
\text { they knowing something } \\
\text { "they are becoming wise" }\end{array}$ & $\begin{array}{l}\text { mbafankwagh } \\
\text { "wisemen" }\end{array}$ \\
\hline 10 & $\begin{array}{l}\text { mba kuhan kwagh } \\
\text { they drumming something } \\
\text { "they are drumming" }\end{array}$ & $\begin{array}{l}\text { mbakuhankwagh } \\
\text { "drummers" }\end{array}$ \\
\hline 11 & $\begin{array}{l}\text { mba kuran ya } \\
\text { they protecting compound } \\
\text { "they are safe guiding the house" }\end{array}$ & $\begin{array}{l}\text { mbakuranya } \\
\text { "the house securities" }\end{array}$ \\
\hline 12 & $\begin{array}{l}\text { mba wan amo } \\
\text { they inserting/singing sons } \\
\text { "they are singing" }\end{array}$ & $\begin{array}{l}\text { mbawanamo } \\
\text { 'singers"' }\end{array}$ \\
\hline 13 & $\begin{array}{l}\text { mba duun amo } \\
\text { they removing songs } \\
\text { "they are composing songs" }\end{array}$ & $\begin{array}{l}\text { mbaduunamo } \\
\text { "song-composers" }\end{array}$ \\
\hline
\end{tabular}




\begin{tabular}{|c|c|c|}
\hline 14 & $\begin{array}{l}\text { mba been ayol } \\
\text { they finishing bodies } \\
\text { "they are becoming old" }\end{array}$ & $\begin{array}{l}\text { mbabeenayol } \\
\text { "old people" }\end{array}$ \\
\hline 15 & $\begin{array}{l}\text { mba gbiden boo } \\
\text { they beating ball } \\
\text { "they are playing ball" }\end{array}$ & $\begin{array}{l}\text { mbagbidenboo } \\
\text { "players" }\end{array}$ \\
\hline 16 & $\begin{array}{l}\text { mba eren msen } \\
\text { they doing prayer } \\
\text { 'they are praying" }\end{array}$ & $\begin{array}{l}\text { mbaerenmsen } \\
\text { "prayer warriors" }\end{array}$ \\
\hline 17 & $\begin{array}{l}\text { or ngohol kpandegh } \\
\text { person collects tax }\end{array}$ & $\begin{array}{l}\text { orngoholkpandegh } \\
\text { (tax collector) }\end{array}$ \\
\hline 18 & $\begin{array}{l}\text { ior mba ngohol kpandegh } \\
\text { people they collecting tax } \\
\text { "people are collecting tax" }\end{array}$ & $\begin{array}{l}\text { iormbangoholkpandegh } \\
\text { "tax collectors" }\end{array}$ \\
\hline 19 & $\begin{array}{l}\text { or civir akombo } \\
\text { human being worships idol } \\
\text { "man worships idol" }\end{array}$ & $\begin{array}{l}\text { orcivirakombo } \\
\text { "an idol worshiper" }\end{array}$ \\
\hline 20 & $\begin{array}{l}\text { ior mba civir akombo } \\
\text { people they worship idols } \\
\text { "people are worshiping idols" }\end{array}$ & $\begin{array}{l}\text { iormbacivirakombo } \\
\text { "idol worshipers" }\end{array}$ \\
\hline 21 & $\begin{array}{l}\text { or keren kwase } \\
\text { man searching woman } \\
\text { "a man womanizers" }\end{array}$ & $\begin{array}{l}\text { orkerenkwase } \\
\text { "a womanizer" }\end{array}$ \\
\hline 22 & $\begin{array}{l}\text { or hemba aondo ga } \\
\text { man surpasses god not }\end{array}$ & $\begin{array}{l}\text { Orhembaaondoga } \\
\text { "someone's name-personal noun" }\end{array}$ \\
\hline 23 & $\begin{array}{l}\text { suur sha ter } \\
\text { "trust on god" }\end{array}$ & $\begin{array}{l}\text { Suurshater } \\
\text { "a female name - personal noun" }\end{array}$ \\
\hline
\end{tabular}

From the table 6 , it could be seen that desententialization is very productive in nominalization in Tiv. Desententialization is a morphologicl process whereby sentences are changed or converted into words (Ajim, 2018:69). In desententialization, sentences are deconstructed (sentence deconstruction) to form words. In the above sentences, the sentences are deconstructed by joining together the linguistic elements that constitute the sentences to form words as in "mba eren tom (they are working)" deconstructed by co-joining the linguistic elements to form the noun "Mbaerentom (workers/labourers).

\section{Contribution to Knowledge}

The paper contributes to knowledge by giving a linguistic insight on nominalization in Tiv. It unveils the processes through which nominalization takes place in the Tiv language such as prefixation, prefixation plus some modifications, tonality and desentenctializtion (sentences deconstruction). The paper proves the extent to which 
these processes are productive in nominalization in Tiv. The paper's posits is that verbs roots and adjectives are the classes of words that are nominalized together with sentences.

\section{Summary and Conclusion}

Nominalization is a linguistic process whereby other words classes and sentences are converted or changed into nouns. On the lexical parlance, verbs and adjectives are nominalized in Tiv. Syntactically sentences are also nominalized through the process of desententialization. Other processes of nominalization in Tiv are prefixation, prefixation with some modifications and tonality. In conclusion, nominalization as a derivative process is very essential in word creation and helps in enriching the Tiv language. As a morphological process, it increases the number of words available in the Tiv language and used in the interactions of the language users.

\section{Recommendations}

Nominalization is evident in many languages of the world therefore, researches should be conducted on this vital morphological process in those languages. This will increase the number of linguistic researches and add to the body of knowledge.

\section{References}

Ajim, S.S., (2018). Analysis of derivational processes in Tiv morphology. M.A Dissertation submitted to postgraduate school, Benue State University, Makurdi.

Anyanwu, O., Omego, C., (2015). Aspects of deverbal nominalization in Tee. In selected proceedings of the $44^{\text {th }}$ Annual conference on African Linguistics, ed. Ruth Kramer et al 1-10, Somerville, M.A

Badejo, B.R., (2014). Morphology: an introduction to the theory of word structure, Cambridge University Press, England.

Chomsky, N., (1968). Remarks on nominalization. In Roderic, J. \& Peter, S. (1970) (ed). Readings in English transformational grammar, Mussachusetts Ginn company, Waltham.

Dauda, M.B., (1971). Lexicalist hypothesis and Hausa, In studies in African Linguistics, 2(3) 197-216.

Haspelmath, M. \& Sims, A. (2010). Understanding Morphology ( $2^{\text {nd }}$ edition), Hodder Education, London.

Hockett, C.F. Two models of grammatical description of words, Word, 10 (1954) $210-234$.

Ikoro, S., (1990). The development and modernization of the Ogoni (Kegboid). Languages for Ogoni unity. Unpublished paper offer to the National Union of Ogoni students, University of Port Harcourt chapter.

Maduagwu, G.O., (2010) Aspects of nominal derivation in Igbo, Nigerian Journal of Research and Production, 16(1) 1-16.

Matthews, P.H., (1974). Morphology: an introduction to the theory of word structure. Cambridge University Press, England.

Maxwell, M.B., (1998). Two theories of morphology, one implementation. SIL electronic working paper. SIL International Publications.

Shibafani, M. \& Awadh, K.M., (2009). Nominalization in Soqotri, a south Arabian Language of Yemen. In Leo, W. Wetzels (ed). The linguistics of endangered languages - contribution to morphology and morpho-syntax, 9 31. Brill, Leiden.

Spencer, A., (1991). Morphological theory: an introduction to word structure in generative grammar. Wiley, New York, USA.

Yule, G., (1996). The study of language. Cambridge University Press, UK. 
Funding

No funding was received for conducting this study.

\section{Conflict of interest}

The authors have no conflicts of interest to declare that they are relevant to the content of this article.

\section{About the License}

(C) The author(s) 2021. The text of this article is open access and licensed under a Creative Commons Attribution 4.0 International License 